\title{
Direct and Indirect Influence of HRM Practices on Employee Performance and Turnover Intention
}

\author{
SUSHILA DEVI RAJARATNAM \\ Research and Consultancy Centre \\ Cooperative College of Malaysia
}

\begin{abstract}
This study attempted to narrow the dearth in the literature with regard to the influence of human resource management (HRM) practices on employees. The study, using a sample of clerical front liners in service-based cooperatives in West Malaysia revealed that HRM practices (training and development, performance appraisal, communication and participation, and rewards) had a significant direct positive and indirect positive relationship with employee performance. The indirect relationship was mediated by affective organisational commitment. In contrast, HRM practices only had an indirect relationship with turnover intention, mediated by affective organisational commitment. Affective supervisory commitment did not mediate the relationship between HRM practices and employee performance nor the relationship between HRM practices and turnover intention. The results suggested that HRM practices can enhance employee performance directly as well as indirectly, through fostering affective organisational commitment. In addition, HRM practices can reduce turnover intention only indirectly through enhancing affective organisational commitment.
\end{abstract}

Keywords: Human resource management; employee outcomes; employee commitment; employee performance; turnover intention; organisational commitment.

\begin{abstract}
ABSTRAK
Kajian ini cuba menyumbang kepada literatur berkaitan dengan amalan Pengurusan Sumber Manusia (PSM) dan kesannya atas pekerja organisasi. Dengan menggunakan sampel yang terdiri daripada pekerja di peringkat perkeranian dalam koperasi berasaskan perkhidmatan, kajian ini mendapati amalan berkaitan pengurusan sumber manusia dari segi latihan dan pembangunan, penilaian prestasi, komunikasi dan penyertaan serta ganjaran, mempunyai hubungan signifikan yang positif secara langsung dan tidak langsung, terhadap prestasi pekerja. Hubungan secara tidak langsung adalah melalui komitmen afektif pekerja terhadap organisasi. Selain itu, amalan berkaitan pengurusan sumber manusia mempunyai hubungan signifikan secara tidak langsung dengan keinginan pusing ganti pekerja, hanya melalui komitmen afektif pekerja terhadap organisasi. Tidak terdapat hubungan di antara amalan pengurusan sumber manusia dengan prestasi pekerja atau, di antara amalan pengurusan sumber manusia dengan keinginan pekerja untuk pusing ganti melalui komitmen afektif terhadap penyelia. Penemuan kajian ini menunjukkan bahawa amalan berkaitan pengurusan sumber manusia mampu meningkatkan prestasi pekerja secara langsung dan secara tidak langsung melalui galakan komitmen afektif mereka terhadap organisasi. Di samping itu, amalan berkaitan pengurusan sumber manusia hanya mampu menurunkan keinginan pekerja untuk pusing ganti secara tidak langsung melalui peningkatan komitmen afektif mereka terhadap organisasi.
\end{abstract}




\section{INTRODUCTION}

One crucial source of competitive success is human resource, therefore it is acknowledged as a special resource deserving managerial attention (Storey, 2001). This acknowledgement has generated considerable interest for research in the field of human resource management (HRM), particularly with regard to understanding the relationship between HRM practices and organisational performance (Wright \& Gardner, 2003). There is still a dearth of research investigating the influence of HRM practices on employees (Wright \& Boswell, 2002). This paucity exists despite the fact that HRM practices are basically targeted toward employees and have the most proximal influence on them. This situation has prompted researchers (Guest, 1997; Wright \& Boswell, 2002) to suggest the need for more studies to examine the relationship between HRM practices and employee outcomes. In fact, Wright and Boswell (2002) highlighted the need for more research to focus on the impact of multiple HRM practices on employees, at the individual level. This is because many prior studies had focused on a specific HRM practice rather than considering a coherent group of HRM practices (Guest, 2002).

The present study attempted to contribute to the literature in two ways. Firstly, the direct and indirect influence of multiple HRM practices on both employee performance and turnover intention was investigated to narrow the paucity of research with regard to the relationship between HRM practices and employee outcomes at the individual level. The employee outcomes examined were the two dependent variables of employee performance and turnover intentions. Though organisational commitment and supervisory commitment have been considered as employee outcomes in prior research, they were examined as mediating variables in this study.

Secondly, to extend the literature on foci of commitment, supervisory commitment was included as a focus of commitment, in addition to organisational commitment. Prior studies (Becker, 1992; Becker, Billings, Eveleth, \& Gilbert, 1996;
Chen, Tsui, \& Farh, 2002; Bentein, Stinglhamber $\&$ Vandenberghe, 2002) have shown that in addition to the organisation, employees can also be committed to their supervisors. Indeed in many organisations, the supervisor is responsible for implementing human resource functions and plays an important role in maintaining good interpersonal relationships in the work place, particularly in a relationship-oriented society like Malaysia (Abdullah \& Low, 2001). Despite the important role played by the supervisor, no published work has examined supervisory commitment as a dependent or mediating variable in relation to multiple HRM practices.

\section{LITERATURE REVIEW}

This section reviews the literature that has explored the relationships between the variables included in the study. Specifically, studies on the relationships between human resource management practices, organisational commitment, employee performance, and turnover intention are reviewed. Next, research evidence on the links between organisational commitment, supervisory commitment, employee performance, and turnover intention are reviewed. The section also justifies the case for including supervisory commitment as a focus of commitment.

\section{Human Resource Management Practices}

Mondy and Noe (2005) defined human resource management as "the utilisation of individuals to achieve organisational objectives". According to them, managers at every level must concern themselves with human resource management. Though there seems to be no consensus with regard to the specific practices that constitute human resource management practices, the literature revealed some practices which have been commonly used in prior studies. These practices are training and development, performance appraisal, performance-based rewards, communication, and employee participation. 


\section{HRM Practices and Organisational Commitment}

Organisational commitment has been defined differently by different researchers (Yousef, 2000). For example, Porter defined it as the relative strength of an individual's identification with and involvement in a particular organisation, and commitment was regarded as focusing on affective commitment (Mowday, 1998). O'Reilly and Chatman (1986) argued that commitment reflects the psychological bond that ties the employee to the organisation and can take three forms: compliance, identification, and internalisation. Compliance reflects behaviour designed to gain rewards; identification occurs when employees behave to maintain a relationship with the organisation due to its attractive values or goals, even though the values or goals may not be personally adopted; and internalisation reflects behaviour driven by internal values or goals that are consistent with those of the organisation.

In recent years however, the most widely cited work on commitment has been done by Meyer and Allen. Meyer and Allen (Meyer \& Allen, 1997) categorised organisational commitment into three components: affective commitment, continuance commitment, and normative commitment. Employees with strong affective commitment remain with the organisation because they want to, employees with strong continuance commitment remain because they need to, and employees with strong normative commitment remain because they feel they ought to. Meyer and Allen (1991) developed an instrument to measure affective, continuance, and normative commitment.

Each of the three scales originally comprised eight items to give a total of 24 items, but a revision of the three scales was later done by Meyer, Allen, and Smith (1993). The revised scales each comprised six items totaling 18 items. Despite the consensus that organisational commitment is a multidimensional construct, prior research has mainly focused on affective commitment, as affective commitment has often had the strongest and most consistent relationship with an individual's desirable behaviour at work (Meyer \& Allen, 1997; Meyer, Stanley, Herscovitvh, \& Topolnytsky, 2002). Hence, the present study also focused on affective organisational commitment and used Meyer and Allen's conceptualisation of affective organisational commitment.

Previous research on commitment has mainly focused on how an employee's commitment to an organisation develops (Meyer \& Allen, 1997) and fewer studies have focused on the relationship between HRM practices and commitment (Meyer \& Smith, 2000). Some prior work has explored the influence of multiple HRM practices on organisational commitment (Agarwala, 2003; Conway, 2004; Meyer \& Smith, 2000; Koh \& Yer, 2000; Paul \& Anantharaman, 2004; Tsui, Pearce, Porter, \& Tripoli, 1997; Whitener, 2001; Yahya, 2000). These studies generally showed that HRM practices positively influenced organisational commitment of employees. Specifically, Yahya (2000) demonstrated that HRM practices (job security, performance appraisal, physical working conditions, training and development, pay, promotion, and benefits) influenced organisational commitment in two large organisations in Malaysia. Meyer dan Smith (2000) demonstrated that the relationship between HRM practices (performance appraisal, benefits, training, and career development) and organisational commitment was not direct but instead mediated by perceptions of organisational support and procedural justice. The positive influence of HRM practices on organisational commitment means that supportive HRM practices are perceived by employees to reflect the organisation's concern for their well-being and, in turn they would reciprocate with increased commitment to the organisation.

\section{HRM Practices and Supervisory Commitment}

Though most commitment literature had addressed commitment to the organisation, employees can also be committed to other foci or targets, such as top management, supervisors, coworkers, and customers (Becker, 1992; Becker et al., 1996; Becker \& Kernan, 2003; Bentein et al., 2002; Chen et al., 2002; Stinglhamber, Bentein \& Vandenberghe, 2002; Swailes, 2004). Foci of commitment are the specific individuals and groups to whom an employee is attached 
(Reichers, 1985). Among these foci, it has been suggested that the supervisor could be the most important foci for employees, due to their proximity and regular interaction with employees (Becker et al., 1996; Chen et al., 2002). Typically, the supervisor has the explicit responsibility for implementing human resource functions and therefore commitment to the supervisor is most likely to have a strong impact on employee behaviour (Becker et al., 1996; Chen, 2001). In the context of Malaysia, which is a relationshiporiented society, the supervisor may play an important role in maintaining good interpersonal relationships in the work place (Abdullah \& Low, 2001). The literature review however, revealed no published work that has explicitly examined the influence of multiple HRM practices on supervisory commitment. Hence, this area of research has been neglected. Besides, since the study was undertaken in Malaysia, the context justified the need to consider the supervisor as a target of commitment in addition to the organisation.

HRM Practices and Employee Performance In general, less research attention has focused on the relationship between multiple HRM practices and employee performance. Employee performance has been assessed as in-role or job performance in some prior work (Becker et al., 1996; Johlke \& Duhan, 2000), or included both in role performance and extra role behaviour, in others (Chen et al., 2002; Tsui et al., 1997; Vandenberghe, Bentein, \& Stinglhamber, 2004). Becker and Kernan (2003) defined in-role performance as the performance of formal tasks, duties, and responsibilities included in a job description, while extra role behaviour refers to activities that are discretionary and goes beyond formal job requirements, such as helping others, being courteous, and making suggestions to improve the organisation.

Generally, HRM practices have been associated with high levels of employee performance (Koh \& Yer, 2000; Tsui et al., 1997; Zerbe, Dobni, \& Harel, 1998). Tsui et al. (1997) explored the effect of four employee-organisation relationships (HRM practices) on employee performance and other employee outcomes. Results indicated that the mutual investment and over-investment approaches (which emphasised on progressive HRM practices) were associated with higher levels of employee performance. The HRM practices in their study referred to investment in training, career development and employment security, employee involvement, and performance-related rewards. Koh and Yer (2000) replicated the framework proposed by Tsui et al. (1997) and found that temporary employees in Singapore managed under the mutual investment and over-investment relationships had better job performance and other outcomes. Zerbe et al. (1998) in a study in service organisations found that HRM practices had a direct effect on employees' self-reported performance and an indirect effect, through service culture. The HRM practices assessed in their study were leadership and direction, rewards and benefits, work demands, career opportunities, performance appraisal, and training.

\section{HRM Practices and Turnover Intention}

Previous research on the relationship between multiple HRM practices and turnover intention (or the converse, intention to stay) had generally reported significant relationships (Batt \& Valcour, 2003; Koh \& Yer, 2000; Tsui et al., 1997). However, a few studies (Guimaraes \& Igbaria, 1992; Lee \& Bruvold, 2003) had demonstrated that HRM practices did not directly influence turnover intention but instead the relationship was fully mediated by job satisfaction and organisational commitment. For example, Lee dan Bruvold (2003) reported that the relationship between investment in training and development (a HRM practice) and turnover intentions of nurses in the United States and Singapore, was fully mediated by job satisfaction and affective organisational commitment. An earlier study by Guimaraes and Igbaria (1992) showed that the HRM practice of organisational communication was fully mediated by job satisfaction and organisational commitment. Thus there is evidence of inconsistency in the findings reported by previous researchers. 


\section{Commitment and Employee Performance}

Organisational commitment and job performance are basically unrelated or have a weak positive relationship. Despite this weak relationship, in their meta-analysis, Meyer et al. (2002) reported that of the three components, affective commitment showed the highest positive correlation with job performance. Earlier Becker et al. (1996) suggested that the failure to consider commitment to foci other than the organisation may partly account for the weak relationship between commitment and job performance. Indeed, studies which included commitment to the supervisor in addition to organisational commitment found that supervisory commitment was positively related to job performance and was more strongly associated with job performance than organisational commitment (Becker et al., 1996; Becker \& Kernan, 2003; Chen et al., 2002; Vandenberghe et al., 2004). Moreover, Vandenberghe et al. (2004) reported that organisational commitment had only an indirect effect on employee performance through supervisory commitment, while supervisory commitment had a direct influence on employee performance. According to Becker and Kernan (2003), affective commitment to the supervisor influenced job performance as supervisors were normally responsible for monitoring, rewarding, and influencing performance.

Interestingly some prior work (Organ \& Ryan, 1995; Vandewalle, Van Dyne \& Kostova, 1995), have also reported that organisational commitment had a stronger influence on extra role behaviour than on in-role performance. Vandenberghe et al. (2004) suggested that the stronger influence may be due to the fact that extra role behaviour is concerned with behaviour that benefits the organisation as a whole, and therefore makes the organisation more salient to employees. Swailes (2004) commented that a stronger relationship has been observed when researchers related commitment to behaviour that is directly within the control of employees rather than using job performance measures, such as sales values which were not within employees' direct control. Most of the prior studies which examined the relationship between commitment and employee performance had focused on affective organisational and affective supervisory commitment. This is because employees with strong affective commitment perform their jobs better than those with weak affective commitment. Also according to Meyer and Allen (1997), not all three forms of commitment, can be associated with high job performance. In terms of the relationship between affective organisational commitment, and affective supervisory commitment, Cheng, Jiang, and Riley (2003) found that both constructs are distinct and positively related.

\section{Commitment and Turnover Intention}

Turnover intention has consistently had a strong and positive relationship with voluntary turnover (Naumann, Widmier, \& Jackson, 2000) and a meta-analysis on turnover (Griffeth, Hom, \& Gaertner, 2000) showed that turnover or quit intentions are the best predictor of turnover and can be used as a surrogate for actual turnover (Lee \& Bruvold, 2003). Meyer and Allen (1991) noted that turnover is the most widely studied correlate of commitment and a significant body of empirical evidence links employees' organisational commitment negatively to turnover intention or turnover (Bishop, Scott, \& Burroughs, 2000; Boshoff \& Mels, 2000; Cheng et al., 2003; Chen \& Francesco, 2000; Fang, 2001; Somers, 1995; Stinglhamber \& Vandenberghe, 2003; Wasti, 2003). In short, the literature indicated that employees with high organisational commitment want to remain with the organisation. Again, previous research had largely focused on affective commitment to the organisation (Clugston, 2000) as affective commitment shows the strongest negative relationship with turnover intention (Meyer et al., 2002).

Though prior studies on turnover intention or turnover have mainly considered commitment to the organisation, the prediction of turnover intention can be improved by considering commitment to other foci which are also relevant (Meyer, et al., 1993). However, fewer studies have investigated the relationship between commitment to more 
than one foci and turnover intention. Some prior work (Becker, 1992; Bishop et al., 2000; Boshoff \& Mels, 2000; Cohen, 2000; Cheng et al., 2003; Chen, 2001; Meyer et al., 1993; Stinglhamber et al., 2002; Vandenberg et al., 2004) had examined commitment to the supervisor, work group or team, top management, career or profession, job or occupation, and customers in addition to the organisation. Specifically, commitment to the supervisor has been investigated in many of these studies (Becker, 1992; Boshoff \& Mels, 2000; Cheng et al., 2003; Chen, 2001; Stinglhamber et al., 2002; Stinglhamber \& Vandenberghe, 2003; Vandenberghe et al., 2004), and this is an indication of the importance of the supervisor as a target of commitment in relation to turnover intentions.

Stinglhamber et al. (2002) extended Meyer and Allen's (1991) three component model of commitment to five foci (organisation, occupation, supervisor, work group, and customers) and examined their influence on intention to leave and subsequently, turnover. Their study demonstrated that commitment directed to foci other than the organisation had a more important influence on intent to quit the organisation than organisational commitment. Chen (2001) reported that loyalty (or commitment) to supervisor was positively related to job satisfaction and intent to stay (the converse of turnover intention) in the People's Republic of China. Moreover, supervisory commitment explained variance in both these outcome variables over and above that explained by organisational commitment. Becker (1992) also reported that commitment to other foci (including supervisory commitment) were important determinants of turnover intention over and above organisational commitment.

However, there have been some conflicting findings with respect to the influence of commitment to supervisor and organisation on turnover intentions. For example, Boshoff and Mels (2000) examined the impact of commitment on profession, organisation, supervisor, and job, and found that commitment to the supervisor and job did not impact on intentions to resign, but commitment to the organisation and profession did influence turnover intentions. In a longitudinal study, Vandenberghe et al. (2004) showed that organisational commitment exerted the strongest direct effect on turnover intention and, in addition, partially mediated the effect of commitment to the supervisor on turnover intention. Their study demonstrated that the impact of organisational commitment on turnover intention was stronger than the impact of supervisory commitment. Interestingly, in both these studies (Boshoff \& Mels, 2000; Vandenberghe et al., 2004) the impact of organisational commitment was stronger than that of commitment to the supervisor and this suggested that the organisation was more relevant or salient to the employees than the supervisor when they had to decide regarding membership in the organisation. Finally, Cheng et al. (2003) reported that both organisational commitment and supervisory commitment were directly and negatively related to turnover intention. According to them, commitment to the supervisor would be considered as an important factor, in addition to organisational commitment, when an employee had to make decisions about quitting the organisation.

\section{THEORETICAL FRAMEWORK, STUDY OBJECTIVES, AND HYPOTHESES}

The review of literature had highlighted the need to focus more research attention to investigate the relationship between multiple HRM practices and employee outcomes at the individual level (Wright \& Boswell, 2002). Since employees are the main target of these practices, empirical studies should firmly establish the relationship between HRM practices and employee outcomes before studying their impact on organisational performance (Guest, 1997). This is necessary to ensure employees' effectiveness and ultimately, the effectiveness of their organisation, more so in the context of service organisations where employees constitute the main input. Hence employee performance and turnover intention are two crucial employee outcomes influenced by HRM practices that would then contribute toward enhancing effectiveness of the individual and the organisation. 
Prior research had mainly focused on the organisation as a target of commitment. Commitment to other important targets, such as the supervisor, has only recently been researched and generally neglected in commitment research. Despite the important role a supervisor plays in explicitly implementing human resource functions, and influencing employee performance and turnover intention, fewer empirical studies had examined the relationship between commitment to the supervisor and employee outcomes, such as employee performance and turnover intention. Also these studies have mainly been carried out in the West, with the exception of a very few in the Asian (Chinese) context. Hence there is a need for more research focusing on supervisory commitment to other Asian countries. Moreover, no prior published work had examined the relationship between multiple HRM practices and supervisory commitment or commitment to the supervisor. Examining this relationship particularly in the context of Malaysia would be relevant because in addition to implementing the human resource functions, the supervisor can play an important role in maintaining good interpersonal relationships in the work place (Abdullah \& Low, 2001).

Organisational commitment and supervisory commitment were included as two mediating variables that would influence the relationship between HRM practices, employee performance, and turnover intention. It was posited that organisational commitment and supervisory commitment are two distinct but related employee attitudes that would be more proximally influenced by HRM practices. Furthermore, based on the literature, HRM practices have a significant relationship with organisational commitment and in turn, organisational commitment has been found to have significant relationship with turnover intention. Though organisational commitment generally has had weak relationship with in-role or job performance, prior research had shown stronger relationship between organisational commitment and extra role behaviour as well as with in-role performance directly within employees' control. This evidence justified the need to consider aspects of in-role performance within the control of the employee as well as extra role behaviour. Finally, commitment studies had generally focused on affective organisational and affective supervisory commitment due to the stronger relationship between affective commitment and desirable employee outcomes.

This study examined the proposed relationships between HRM practices, affective organisational commitment, affective supervisory commitment, employee performance, and turnover intention in the context of cooperatives, since no such study has been attempted using cooperatives as the research setting. It is an exploratory study as no published work has investigated these relationships within the same model.

The specific objectives were:

(a) to examine the direct relationship between HRM practices and employee performance;

(b) to examine the direct relationship between HRM practices and turnover intention;

(c) to examine the indirect influence of HRM practices on employee performance, through the mediating effects of affective organisational commitment and affective supervisory commitment; and

(d) to examine the indirect influence of HRM practices on turnover intention, through the mediating effects of affective organisational commitment and affective supervisory commitment.

The proposed model is shown in Figure 1.

In Figure 1, HRP refers to human resource management practices and includes the four practices of training and development (t\&d), communication and participation (c\&p), performance appraisal (pa), and rewards (rd). Affective organisational commitment is labeled aoc and affective supervisory commitment is labeled asc. Employee performance is labeled $\mathrm{EP}$ and turnover intention is labeled ti. HRP is the independent factor, aoc and asc are the two mediating factors, while EP and ti are the two dependent factors. 


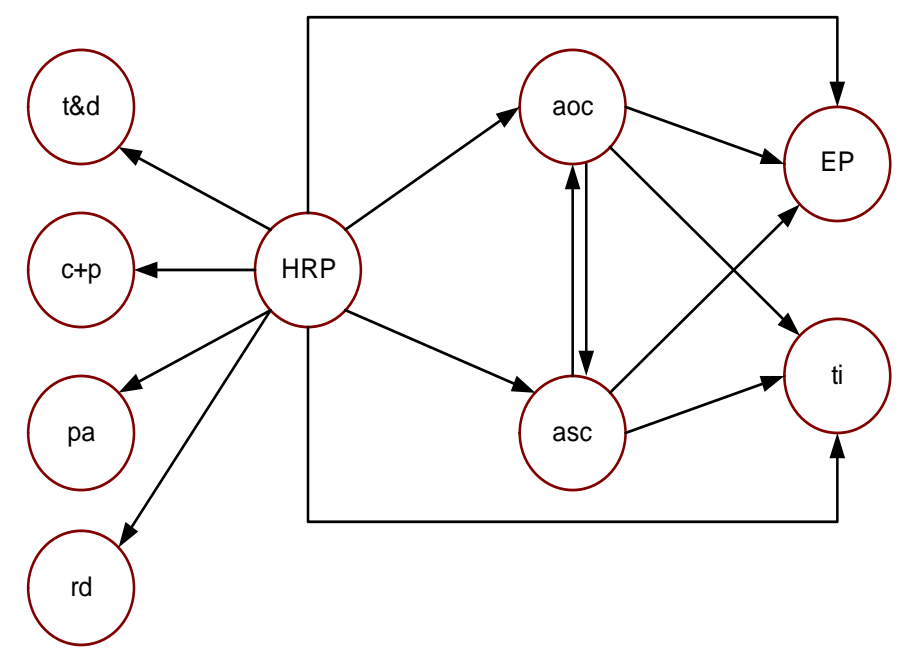

Figure 1

Relationship between HRM practices (HRP), affective organisational commitment (aoc), affective supervisory commitment (asc), employee performance (EP), and turnover intention (ti)

The following 10 hypotheses were proposed and tested for their significance:

$\mathrm{H}_{1}$ : There is a significant direct relationship between HRM practices and employee performance.

$\mathrm{H}_{2}$ : There is a significant direct relationship between HRM practices and turnover intention.

$\mathrm{H}_{3}$ : There is a significant direct relationship between HRM practices and affective organisational commitment.

$\mathrm{H}_{4}$ : There is a significant direct relationship between affective organisational commitment and employee performance.

$\mathrm{H}_{5}$ : There is a significant direct relationship between affective organisational commitment and turnover intention.

$\mathrm{H}_{6}$ : There is a significant direct relationship between affective supervisory commitment and employee performance.

$\mathrm{H}_{7}$ : There is a significant direct relationship between affective supervisory commitment and turnover intention.

$\mathrm{H}_{8}$ : There is a significant direct relationship between affective organisational commitment and affective supervisory commitment.
$\mathrm{H}_{9}$ : The relationship between HRM practices and employee performance is mediated by affective organisational commitment.

$\mathrm{H}_{10}$ : The relationship between HRM practices and turnover intention is mediated by affective organisational commitment.

The following three propositions were also suggested to contribute to the literature:

Proposition 1:

There is a significant direct relationship between HRM practices and affective supervisory commitment.

\section{Proposition 2:}

The relationship between HRM practices and employee performance is mediated by affective supervisory commitment.

\section{Proposition 3:}

The relationship between HRM practices and turnover intention is mediated by affective supervisory commitment. 


\section{RESEARCH METHOD}

\section{Sample and Data Collection}

The sample consisted of clerical front line employees from 140 service-based cooperatives in West Malaysia, with a minimum of five paid employees. The study was confined to servicebased cooperatives as they represent $85 \%$ of cooperatives (excluding school cooperatives) in West Malaysia (Malaysia, Cooperative Development Department Statistics, 2005). West Malaysia was selected since $80 \%$ of the servicebased cooperatives are in West Malaysia and clerical front line employees were targeted as they comprise the majority of employees in the cooperatives. Service-based cooperatives with a minimum of five paid employees were identified to ensure the existence of HRM practices. The cooperatives were contacted directly to obtain their cooperation to participate in the survey. The heads of the cooperatives were co-opted as intermediaries to gain access to the respondents and to facilitate data collection. The questionnaires and explanatory letters were mailed directly to these intermediaries to be distributed to the respondents, together with pre-stamped envelopes for every respondent. The cooperatives were requested to return the questionnaires directly to the researcher in the envelopes provided. Mail survey was used due to cost and time constraints as the cooperatives are scattered in different states in West Malaysia. In total, 1000 questionnaires were mailed to the cooperatives and out of 540 responses received, 516 were usable for analysis, indicating a response rate of $51.6 \%$. This response rate compares favourably with the $30 \%$ considered acceptable for mail surveys (Sekaran, 2000).

The sample consisted of $68 \%$ females and $87 \%$ were Malays. In addition, $71 \%$ of the respondents were 40 years old and less, while $70 \%$ had SPM/MCE as their highest qualification. In terms of organisational tenure, $60 \%$ of the sample had worked for a maximum of 10 years in the cooperatives.

\section{Measures}

All multi-item scales were measured on a fivepoint Likert scale ranging from strongly disagree (1) to strongly agree (5).

\section{Human resource management practices}

As there is no existing scale to measure the perception of HRM practices among clerical front liners in service-based cooperatives, this scale was developed by reviewing the literature and adapting the items from previous studies (Conway, 2004; Delery \& Doty, 1996; Khatri, 2000; Liao \& Chuang, 2004; Whitener, 2001; Vandenberg \& Eastman, 1999). Four HRM practices were used in the study. The four practices were identified from the literature and adapted to suit the Malaysian cooperative context after obtaining feedback from the management of the service-based cooperatives. They were training and development (11 items), performance appraisal (9 items), communication and participation ( 8 items), and rewards ( 7 items). Reliability of this scale was tested by computing Cronbach's alpha value, and the four factors had Cronbach's alpha values higher than 0.6 , a cut off value regarded as acceptable in exploratory research (Hair, Black, Babin, Anderson \& Tatham, 2006). Specifically, the coefficient alpha values for training and development, performance appraisal, communication and participation, and reward were $0.81,0.66,0.80$ and 0.66 , respectively.

\section{Organisational commitment}

The study assessed affective commitment to the cooperative organisation and was measured using four items adapted from the six item affective organisational commitment scale developed by Meyer, Allen, and Smith (1993), to suit the target and context of this study. Using shortened scales to measure affective commitment had been attempted before by Bentein et al. (2002). The four items had a coefficient alpha of 0.80 .

\section{Supervisory commitment}

Affective commitment to the supervisor was assessed using four items adapted from the six item affective supervisory commitment scale developed by Stinglhamber et al. (2002), to suit the target and study context. The four items had a coefficient alpha of 0.84 .

\section{Employee performance}

Employee performance was measured in terms of in-role and extra role performance that was 
relevant to clerical front line employees in service-based cooperatives. In-role performance was assessed with 21 items adapted to suit the research context from prior studies (Chen et al., 2002; Singh, 2000; Suliman, 2001; Johlke \& Duhan, 2000; Liao \& Chuang, 2004; Welbourne, Johnson, \& Erez, 1998). The coefficient alpha for this scale was 0.88. Extra role performance was measured with 14 items adapted to suit the research context from previous work (Becker \& Kernan, 2003; Bentein et al., 2002; Bettencourt \& Brown, 1997; Organ \& Konovsky, 1989; Podsakoff, Ahearne, \& Mackenzie, 1997). The internal consistency of this scale was 0.81 .

\section{Turnover intention}

Turnover intention was measured with three items adapted from Cook, Hepworth, Wall, dan Warr (1981). The internal consistency reliability was tested using Cronbach's coefficient alpha and it was 0.70 .

The face validity of the survey questionnaire was established after a review by practitioners and a pilot test.

\section{RESULTS}

\section{Structural Equation Modelling}

The structural equation modelling (SEM) technique using AMOS software was used to analyse the relationships between the factors in the proposed model. SEM was used because it enables the simultaneous calculation of both the direct and indirect effects of HRM practices on employee performance and turnover intention. The SEM analysis was carried out in two stages. In the first stage, a total of nine factors or measurement models were validated using the goodness-of-fit indices, specifically Root Mean Square of Approximation (RMSEA), Comparative Fit Index (CFI) and the Tucker Lewis Index (TLI). The nine measurement models were communication and participation (c\&p), reward (rd), training and development $(\mathrm{t} \& d)$, performance appraisal (pa), affective organisational commitment (aoc), affective supervisory commitment (asc), in-role or job performance (jp), extra role behaviour (erb), and turnover intention (ti). Overall, the nine measurement models had acceptable fit for the data as indicated by the CFI and TLI values exceeding 0.90 . In addition, the RMSEA values were also less than the recommended cut off value of 0.08 for all the measurement models, except for affective supervisory commitment. However, since the CFI and TLI values both exceeded 0.90, this factor showed acceptable fit for the data.

\section{Factor Correlations}

Correlation between the nine factors was examined using the AMOS programme. The correlations reflect the strength of association between any two factors. Table 1 displays the correlations of the nine factors, communication and participation (c\&p), reward (rd), training and development (t\&d), performance appraisal (pa), affective organisational commitment (aoc), affective supervisory commitment (asc), in-role or job performance (jp), extra role behaviour (erb) and turnover intention (ti). To enhance model parsimony, nine items with loadings of less than 0.40 on the respective factors were excluded. Table 1 shows the factor correlations after exclusion of these items.

Overall, the results in Table 1 show that the factors are either positively or negatively associated to one another. Specifically, communication and participation (c\&p) showed moderate to high positive correlations with affective organisational commitment (aoc), affective supervisory commitment (asc), job performance (jp), and extra role behaviour (erb). Communication and participation (c\&p) correlated negatively and moderately with turnover intention (ti). Reward (rd) correlated positively and highly with affective organisational commitment (aoc), and affective supervisory commitment (asc), but displayed moderate positive associations with job performance (jp) and extra role behavior (erb). It showed moderate negative correlation with turnover intention (ti). Training and development $(t \& d)$ correlated highly and positively with affective organisational commitment (aoc), and had moderate positive association with affective supervisory commitment (asc), job performance (jp), and extra role behaviour (erb). 
The correlation with turnover intention (ti) was moderate and negative. Performance appraisal (pa) had high positive correlations with affective organisational commitment (aoc) and affective supervisory commitment (asc), and moderate positive associations with both job performance (jp) and extra role behaviour (erb). The correlation with turnover intention (ti) was negative and moderate.

Table 1

Factor Correlations

\begin{tabular}{|c|c|c|c|}
\hline & Factor & & Correlations \\
\hline$c \& p$ & With & aoc & .593 \\
\hline c\&p & With & asc & .688 \\
\hline c\&p & With & jp & .450 \\
\hline$c \& p$ & With & erb & .505 \\
\hline$c \& p$ & With & $\mathrm{ti}$ & -.334 \\
\hline $\mathrm{rd}$ & With & aoc & .695 \\
\hline $\mathrm{rd}$ & With & asc & .528 \\
\hline rd & With & jp & .321 \\
\hline $\mathrm{rd}$ & With & erb & .389 \\
\hline $\mathrm{rd}$ & With & ti & -.348 \\
\hline $\mathrm{t} \& \mathrm{~d}$ & With & aoc & .631 \\
\hline $\mathrm{t} \& \mathrm{~d}$ & With & asc & .449 \\
\hline t\&d & With & jp & .392 \\
\hline t\&d & With & erb & .419 \\
\hline $\mathrm{t} \& \mathrm{~d}$ & With & ti & -.326 \\
\hline pa & With & aoc & .561 \\
\hline pa & With & asc & .511 \\
\hline pa & With & jp & .392 \\
\hline pa & With & erb & .475 \\
\hline pa & With & $\mathrm{ti}$ & -.311 \\
\hline aoc & With & jp & .456 \\
\hline aoc & With & erb & .464 \\
\hline aoc & With & $\mathrm{ti}$ & -.529 \\
\hline asc & With & jp & .388 \\
\hline asc & With & erb & .478 \\
\hline asc & With & $\mathrm{ti}$ & -.346 \\
\hline aoc & With & asc & .623 \\
\hline jp & With & ti & -.236 \\
\hline erb & With & $\mathrm{ti}$ & -.261 \\
\hline
\end{tabular}

Affective organisational commitment (aoc) had moderate positive correlation with job performance (jp) and extra role behaviour (erb), but high negative association with turnover intention (ti). Affective supervisory commitment (asc) had moderate positive associations with job performance (jp) and extra role behaviour (erb), and moderate negative correlation with turnover intention (ti). Affective organisational commitment (aoc) had high positive correlation with affective supervisory commitment (asc). Finally, job performance (jp) and extra role behaviour (erb) showed low negative correlation with turnover intention (ti).

Communication and participation (c\&p), training and development (t\&d), performance appraisal (pa), and reward (rd) were very highly and positively associated and were thus grouped together to form a more general latent factor called human resource management practices (HRP). Schumacker and Lomax (2004) suggested that factors are highly correlated when they are related to a more general factor. Generally, as HRM practices are interdependent and integrated, they are also highly correlated (Ichniowski, Shaw, \& Prennushi, 1997; Meyer \& Allen, 1997; Paul $\&$ Anantharaman, 2004). Since the factors job performance and extra role behaviour were also highly interrelated, they were grouped together and called employee performance (EP). The high correlation between job performance and extra role behaviour is not unusual because an overlap may often occur between both these factors due to the difficulty in identifying all job related behaviour of front line employees in service-based organisations (Bettencourt \& Brown, 1997).

In the second stage, the overall fit of the structural model was tested and the relationships between the factors, namely HRM practices (HRP), affective organisational commitment (aoc), affective supervisory commitment (asc), employee performance (EP), and turnover intention (ti), were analysed. In the model, HRP was the independent factor, both aoc and asc were mediating factors, while EP and turnover intention ti were the dependent factors. After stabilising for errors, the structural model yielded an acceptable fit to the data, with a CFI of 0.92, TLI of 0.91, and RMSEA of 0.033 . The results obtained are presented in Figure 2. Only relationships that were significant $(\mathrm{p}<0.05)$ are shown. 


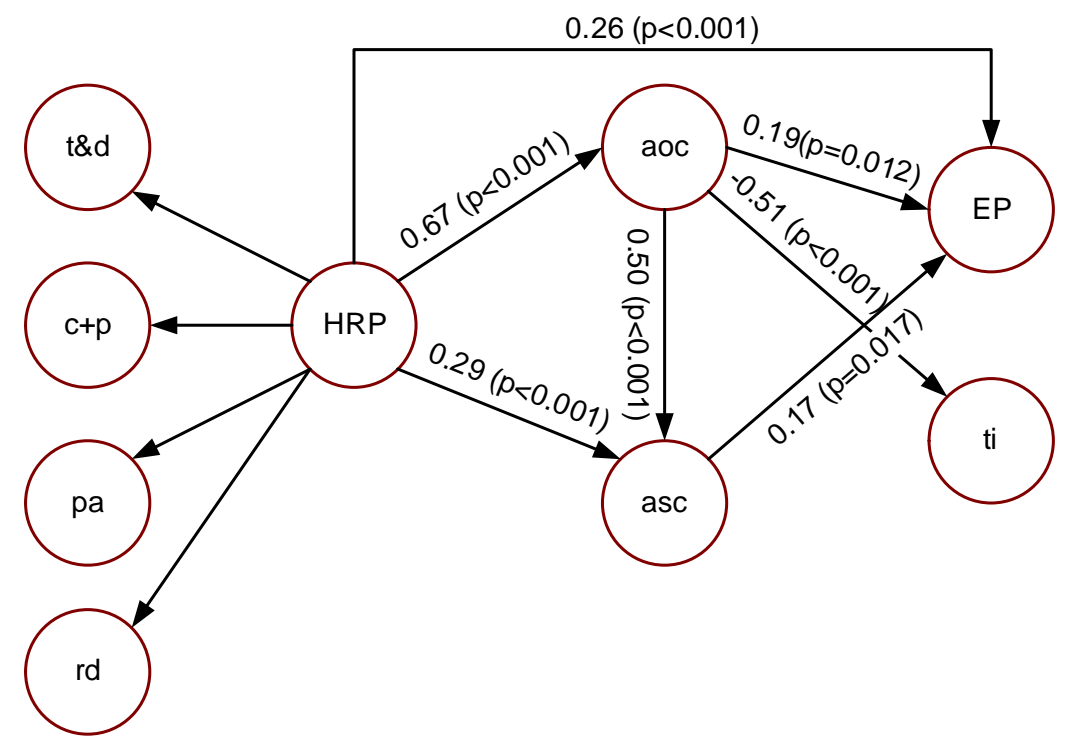

Figure 2

Standardised path coefficients for the partially mediated model

\section{Hypothesis Testing: Direct Relationships}

In testing Hypothesis 1, the direct relationship between HRM practices (HRP) and employee performance (EP) as indicated by the path $(\mathrm{HRP} \rightarrow \mathrm{EP})$ was significant $(\mathrm{p}<0.001)$. The size of the direct effect was 0.26 and the relationship was positive. In testing Hypothesis 2, the direct relationship between HRM practices (HRP) and turnover intention (ti), the path $(\mathrm{HRP} \rightarrow \mathrm{ti})$ was not significant $(\mathrm{p}>0.05)$. Thus there was no significant relationship between HRM practices and turnover intention. In testing Hypothesis 3, the relationship between HRM practices (HRP) and affective organisational commitment (aoc), indicated by the path (HRP $\rightarrow$ aoc $)$, was significant $(p<0.001)$. The size of the direct effect was 0.67 and the relationship was positive. In testing Hypothesis 4, the direct relationship between affective organisational commitment (aoc) and employee performance (EP), the path (aoc $\rightarrow E P)$, was significant $(\mathrm{p}<0.05)$. The size of the direct effect was 0.19 and the relationship was positive. In testing Hypothesis 5, the direct relationship between affective organisational commitment (aoc) and turnover intention (ti), the path (aoc $\rightarrow$ ti) was significant $(\mathrm{p}<0.001)$. The size of the direct effect was 0.51 and the relationship was negative.

In testing Hypothesis 6, the direct relationship between affective supervisory commitment (asc) and employee performance $(\mathrm{EP})$, or the path (asc $\rightarrow \mathrm{EP})$, was significant $(p<0.05)$. The size of the direct effect was 0.17 and the relationship was positive. In testing Hypothesis 7, the direct relationship between affective supervisory commitment (asc) and turnover intention (ti), the path (asc $\rightarrow$ ti) was not significant $(p>0.05)$. There was no significant relationship between affective supervisory commitment and turnover intention. In testing Hypothesis 8, a non-recursive pattern of relationship was tested between affective organisational commitment (aoc) and affective supervisory commitment (asc). The test of affective organisational commitment onto affective supervisory commitment was significant $(\mathrm{p}<0.001)$, but the test of affective supervisory commitment onto affective organisational commitment was not significant $(\mathrm{p}>0.05)$. The size of the direct effect was 0.50 and the relationship was positive. Hence, there was no non-recursive relationship between affective organisational commitment and affective supervisory commitment but 
instead, there was a recursive relationship from affective organisational commitment onto affective supervisory commitment. In testing proposition 1, the direct relationship between HRM practices (HRP) and affective supervisory commitment (asc) or the path (HRP $\rightarrow$ asc) was significant $(\mathrm{p}<0.001)$. The size of the direct effect was 0.29 and the relationship was positive.

\section{Hypothesis Testing: Indirect Relationships}

The mediating influence of affective organisational commitment (aoc) and affective supervisory commitment (asc) on the relationship between HRM practices (HRP) and employee performance (EP) were tested. The results are displayed in Table 2.

\section{Table 2}

Relationship between HRM Practices and Employee Performance

\begin{tabular}{cc}
\hline Direct Relationship & Direct Effect \\
\hline $\mathrm{HRP} \rightarrow$ EP & 0.26 \\
Indirect Relationship & Indirect Effect \\
$\mathrm{HRP} \rightarrow$ aoc $\rightarrow$ EP & 0.13 \\
$\mathrm{HRP} \rightarrow$ asc $\rightarrow$ EP & 0.05 \\
\hline
\end{tabular}

Table 2 shows that the direct relationship between HRP and EP was significant $(\mathrm{p}<0.001)$ and positive. Indirect relationships refer to "relationships that involve a sequence of relationships with at least one intervening construct. Thus an indirect effect is a sequence of two or more direct effects." (Hair et al., 2006, p. 868). In the indirect relationship between HRM practices and employee performance, the two mediating or intervening constructs were affective organisational commitment and affective supervisory commitment. The path $(\mathrm{HRP} \rightarrow \mathrm{aoc} \rightarrow$ EP) tested Hypothesis 9. The size of the indirect effect for the path (HRP $\rightarrow$ aoc $\rightarrow$ EP) was 0.13 and the relationship was positive. According to Hair et al. (2006), an indirect effect which is less than
0.08 is regarded as trivial relative to the strength of the direct path, and therefore the indirect effect is not important. In this case, the indirect effect of 0.13 was greater than 0.08 . Hence, affective organisational commitment was a mediator on the relationship between HRP and EP. In addition, as the direct relationship between HRP practices and employee performance was also significant, affective organisational commitment was a partial mediator. Thus the relationship between HRP and EP was partially mediated by affective organisational commitment.

The path $(\mathrm{HRP} \rightarrow$ asc $\rightarrow$ EP $)$ tested Proposition 2. The size of the indirect effect for this path was 0.05 and the relationship was positive. However, since this value is less than 0.08 , affective supervisory commitment did not mediate the relationship between HRP and EP. Hence, the relationship between them was not mediated by affective supervisory commitment.

Overall, the resulted suggested that the relationship between the human resource management practices and employee performance was partially mediated by affective organisational commitment. HRM practices had both a significant direct and an indirect influence on employee performance. However, based on the size of the standardised effects, the direct relationship was stronger than the indirect relationship. The indirect influence was only through the mediating role of affective organisational commitment. On the other hand, affective supervisory commitment did mediate the relationship between HRM practices and employee performance.

The mediating influence of affective organisational commitment (aoc) and affective supervisory commitment (asc) on the relationship between HRM practices (HRP) and turnover intention (ti) were also tested and the results are presented in Table 3.

Table 3 shows that the direct relationship between HRP and turnover intention was not significant $(\mathrm{p}>0.05)$. The path $(\mathrm{HRP} \rightarrow \mathrm{aoc} \rightarrow \mathrm{ti})$ tested Hypothesis 10. The size of the indirect effect for this path was -0.34 and the relationship was negative. As this value is greater than 0.08 , affective organisational commitment was a mediator on the relationship between HRP and turnover intention. Since the direct relationship 
between HRP and turnover intention was not significant, affective organisational commitment was a full mediator. Thus the relationship between HRP and turnover intention was fully mediated by affective organisational commitment. The path $(\mathrm{HRP} \rightarrow \mathrm{asc} \rightarrow \mathrm{ti})$ tested Proposition 3. The size of the indirect effect for this path was 0.003 and the relationship was negative. However, since this value is less than 0.08 , affective supervisory commitment did not mediate the relationship between HRP and turnover intention. Hence, the relationship between HRP and turnover intention was not mediated by affective supervisory commitment.

\section{Table 3}

Relationship between HRM Practices and Turnover Intention

\begin{tabular}{cc}
\hline Direct Relationship & Direct Effect \\
\hline $\mathrm{HRP} \rightarrow \mathrm{ti}$ & -0.03 \\
Indirect Relationship & Indirect Effect \\
$\mathrm{HRP} \rightarrow$ aoc $\rightarrow \mathrm{ti}$ & -0.34 \\
$\mathrm{HRP} \rightarrow \mathrm{asc} \rightarrow \mathrm{ti}$ & -0.003 \\
\hline
\end{tabular}

Overall, the results suggested that the relationship between the human resource management practices and turnover intention was fully mediated by affective organisational commitment. HRM practices did not have a significant direct influence on turnover intention. HRM practices had only an indirect influence on turnover intention and this indirect influence was only mediated by affective organisational commitment. In contrast, affective supervisory commitment did not mediate the relationship between HRM practices and turnover intention.

\section{DISCUSSION}

The results of this study provided some interesting implications. Firstly, the finding of a significant and positive direct influence of HRM practices on employee performance obtained in this study is consistent with the results of prior studies (Koh \& Yer, 2000; Tsui et al., 1997; Zerbe et al., 1998). When employees believed that their organisations were having supportive HRM practices related to training and development, communication and participation, performance appraisal, and rewards, they were likely to perceive these actions as showing concern and making investments in them. In return, the employees were also likely to reciprocate by improving their performance on core tasks (inrole performance) and engaging in extra role behaviour beneficial to their organisation.

The finding of a significant and positive direct influence of HRM practices on affective organisational commitment is consistent with those of previous research (Agarwala, 2003; Koh \& Yer, 2000; Paul \& Anantharaman, 2004; Tsui et al., 1997). These studies also focused on affective organisational commitment. This finding implied that the more positively employees perceive the HRM practices in their organisation, the greater their level of affective organisational commitment. HRM practices which are perceived by employees as being supportive reflect the organisation's concern and investment for their personal development and well-being. In return, employees are likely to increase their affective commitment to the organisation. Therefore, by using HRM practices, organisations can demonstrate their support for employees and in return foster employees' affective commitment (Meyer \& Smith, 2000).

The current study extended research on commitment by proposing and finding a significant positive direct relationship between HRM practices and affective supervisory commitment. This result justifies the theoretical rationale that the supervisor has a responsibility for implementing HRM functions in an organisation. Specifically, practices such as performance appraisal, and communication and participation, which involve the supervisor directly, may also be perceived by employees as reflecting the supervisor's concern for their well-being. In return, they tend to reciprocate with increased affective commitment to their supervisor. As indicated by 
the standardised coefficient values, the strength of the direct positive relationship between HRM practices and affective organisational commitment is double the strength of the direct positive relationship between HRM practices and affective supervisory commitment. One possible explanation for the stronger link between HRM practices and affective organisational commitment as compared to the relationship between HRM practices and affective supervisory commitment is that some HRM functions in the organisation may not be carried out by the supervisor. Instead, some of the functions may be carried out directly by managers and /or the board members of the cooperatives. It is thus likely that the supervisor may be perceived to be less important than the organisation in implementing the HRM practices.

The result of a significant and positive direct relationship between affective organisational commitment and employee performance indicates that when employees perceive a higher level of affective organisational commitment, they tend to perceive a higher level of performance on their part. When employees have more affective commitment to their organisation, they tend to have a sense of belonging which would then encourage them to improve their performance. The evidence of a significant and positive direct relationship between supervisory commitment and employee performance implies that commitment to a proximal target, the supervisor, does have a positive influence on employee performance. However, the evidence of a direct relationship between affective organisational commitment and employee performance, which is slightly stronger than the direct relationship between supervisory commitment and employee performance, means that the organisation is perceived to be a more salient target of commitment than the supervisor. A plausible reason for this is that the supervisor's role in implementing HRM functions may have been underutilised by management and subsequently, the supervisor may have been perceived by employees as having less influence on their performance as compared to their organisation.

The partially mediated influence of HRM practices on employee performance suggests that
HRM practices are effective tools to enhance employee performance directly, and indirectly, through establishing and maintaining affective organisational commitment. Importantly then, the management must systematically design and implement an integrated HRM system comprising practices related to training and development, communication and participation, performance and rewards which would motivate employee performance, directly and indirectly, through fostering affective commitment to the organisation. Since HRM practices are highly interrelated Ichniowski et al., 1997), an integrated HRM system would therefore achieve the desired impact on employee outcomes (Meyer \& Allen, 1997).

This study demonstrated that affective organisational commitment had a significant and negative relationship with turnover intention. This finding is consistent with those of previous studies (Boshoff \& Mels, 2000; Cheng et al., 2003; Chen \& Francesco, 2000; Fang, 2001). An important implication of this finding is that employees' emotional attachment, identification with, and involvement with their organisation is very important in influencing their turnover intentions. In contrast, the finding of no significant relationship between affective supervisory commitment and turnover intention was in accordance with the finding of Boshoff and Mels (2000), who also found that organisational commitment had a significant relationship with turnover intention but supervisory commitment did not. Boshoff and Mels (2000) reasoned that employees relate turnover intentions to how they feel about their organisation rather than their feelings toward a proximal focus, such as the supervisor. In other words, affective commitment to the organisation appears to be more relevant to employees than affective commitment to the supervisor when they had to make decisions on whether to quit their organisations.

The finding of no significant direct relationship between HRM practices and turnover intention is consistent with some prior work (Guimaraes \& Igbaria, 1992; Lee \& Bruvold, 2003). Both the studies reported that affective organisational commitment fully mediated the influence of single HRM practices on turnover 
intention. In the present study too, affective organisational commitment fully mediated the relationship between HRM practices and turnover intention. The results suggested that employees have greater affective commitment to their organisation when they have more positive perceptions toward HRM practices in their organisation, and this reduces their intention to leave. Hence, when the employer invests in supportive HRM practices, it is likely that employees believe that the organisation is interested in their well-being and in return, they are likely to reciprocate with increased affective commitment to their organisation. Subsequently, this increased affective commitment will then reduce their desire to leave their organisation. Hence, it is clearly evident that only when affective commitment to the organisation is enhanced, would the turnover intention of clerical front liners be reduced. An important implication is that investment in complementary HRM practices can be effectively used to reduce turnover intentions only through enhancing affective organisational commitment. Since, turnover can be costly, especially when well performing employees leave employers should strive to foster affective organisational commitment and consequently reduce employees' desire to leave by investing in an integrated group of supportive training and development practices, performance appraisal, rewards, as well as communication and participation programmes. Overall, the results of this study pointed out the importance of affective organisational commitment in organisations to enhance employee performance and reduce turnover intentions.

\section{CONCLUSION}

This study investigated the simultaneous relationships between a group of HRM practices, affective organisational commitment, affective supervisory commitment, employee performance, and turnover intentions. No published work has undertaken such a study. Moreover, this is the first time this study has been undertaken in the cooperative sector in Malaysia. In short, the results of the study provide evidence of a partially mediated relationship between HRM practices and employee performance, where affective organisational commitment was the partial mediator. In other words, there was a significant positive direct as well as an indirect relationship between HRM practices and employee performance. The indirect relationship was mediated by affective organisational commitment. This finding implied that HRM practices are indeed an effective tool to enhance employee performance directly as well as indirectly, through fostering affective organisational commitment to their employees. In contrast, there was evidence of only an indirect relationship between HRM practices and turnover intention that was fully mediated by affective organisational commitment. This result suggested that employees' desire to leave their organisation is reduced only when affective commitment to their organisation is enhanced. Therefore, in order to reduce turnover intention, HRM practices must be targeted towards enhancing employees' affective organisational commitment. In general, it is imperative that in order to effectively enhance employee performance and reduce turnover intentions, a complementary and coordinated system of supportive HRM practices related to training and development, communication and participation, performance appraisal, and rewards, is designed and implemented for employees.

Specifically, training and development programmes should focus on enhancing skills and providing opportunities for personal development so that employees would have the competence to perform their jobs well, as well as the necessary skills to compete for jobs within their organisation. In addition, a career development path should be planned for clerical front line employees and communicated so that they are aware of the available opportunities and the required competencies for advancement within their organisation. A systematic and effective performance appraisal system should be designed and instituted for clerical front liners. This system should focus on joint goal setting (by supervisor and employee), regular appraisals which emphasise achievement of job targets, as well as a performance-based reward system 
which gives due recognition to well-performing employees. Finally, an effective communication and participation system should be implemented to encourage information sharing and employee involvement in work related decision making. Regular communication between the management and employees should equip employees with the latest information on the policies and procedures related to the organisation as well as, encourage employee participation through obtaining feedback and suggestions. In addition, employees should be allowed some autonomy in work related decision making so that they are able to perform their duties with minimum interference and delay.

The study has made some significant contribution to the literature. The finding of a significant positive relationship between human resource management practices and supervisory commitment is an important contribution to the literature on commitment. The study provided cross-cultural evidence of the positive relationship between supervisory commitment and employee performance and this has augmented the limited existing studies on this relationship. Finally, the study contributed to the broader understanding of the indirect influence of HRM practices on employee performance and turnover intention.

Some limitations to the study and suggestions for future research were identified. Though structural equation modeling technique was used to analyse the data, causal inferences could not be drawn as the simultaneous relationships between HRM practices, affective organisational commitment, affective supervisory commitment, employee performance and turnover intention, were measured at the same time, due to cost and time constraints. A longitudinal design would enable actual causal relationships to be observed. Only affective organisational commitment and affective supervisory commitment were assessed in this study. Moreover, the scales to measure affective organisational commitment and affective supervisory commitment were shortened to suit the context of this study. Future studies could use the original organisational commitment scale by Meyer et al. (1993) and the original supervisory commitment scale by Stinglhamber et al. (2002) to determine their cross-cultural validity. This study focused on affective commitment to the organisation and affective commitment to the supervisor. Future studies can extend the foci of commitment to include other foci of relevance, such as affective commitment to co-workers and affective commitment to customers, to determine which of these foci have the most influence on employee performance and turnover intentions.

The study deliberately focused on obtaining responses for all the variables from the employees. For the purpose of this study, it was their perceptions that were relevant, not the perception of management. This is because employees' perceptions of reality have been acknowledged as being more likely to influence their behaviour than formal documented policies on HRM (Meyer \& Allen, 1997). Though the results were generally consistent with those of previous work, future research can also include the perspective of the employer to obtain a more complete picture. The focus of this study was to investigate the influence of human resource management practices on front line clerical employee outcomes (employee performance and turnover intentions). Future studies can extend this model to investigate the influence of human resource management practices on organisational performance of cooperatives. Finally, more studies need to be undertaken to confirm the finding in this study that HRM practices are significantly and positively related to affective supervisory commitment.

\section{REFERENCES}

Abdullah, A., \& Low, A. H. M. (2001). Understanding the Malaysian workforce: Guidelines for managers. Kuala Lumpur: Malaysian Institute of Management.

Agarwala, T. (2003). Innovative human resource practices and organisational commitment: An empirical investigation. The International Journal of Human Resource Management, 14 (2), 175-197.

Batt, R., \& Valcour, P. M. (2003). Human resources practices as predictors of workfamily outcomes and employee turnover. Industrial Relations, 42(2), 189-220. 
Becker, T.E. (1992). Foci and bases of commitment: Are they distinctions worth making? Academy of Management Journal, 35(1), 232-244.

Becker, T.E., Billings, R. S., Eveleth, D.M., \& Gilbert, N.L. (1996). Foci and bases of employee commitment: Implications for job performance. Academy of Management Journal, 39(2), 464-482.

Becker, T.E., \& Kernan, M.C. (2003). Matching commitment to supervisors and organisations to in-role and extra-role performance. Human Performance, 16(4), 327-348.

Bentein, K., Stinglhamber, F., \& Vandenberghe, C. (2002). Organisation, supervisor, and workgroup-directed commitments and citizenship behaviours: A comparison of models. European Journal of Work and Organizational Psychology, 11(3), 341362.

Bettencourt, L.A., \& Brown, S.W. (1997). Contact employees: Relationships among workplace fairness, job satisfaction and prosocial service behaviours. Journal of Retailing, 73(1), 39-61.

Bishop, J.W., Scott, K.D., \& Burroughs, S.M. (2000). Support, commitment and employee outcomes in a team environment. Journal of Management, 26(5), 1113-1132.

Boshoff, C., \& Mels, G. (2000). The impact of multiple commitments on intentions to resign: An empirical assessment. British Journal of Management, 11(3), 255-273.

Cheng, B., Jiang, D., \& Riley, J.H. (2003). Organisational commitment, supervisory commitment, and employee outcomes in the Chinese context: Proximal hypothesis or global hypothesis? Journal of Organizational Behavior, 24, 313-334.

Chen, Z. (2001). Further investigation of the outcomes of loyalty to supervisor: Job satisfaction and intention to stay. Journal of Managerial Psychology, 16(8), 650-660.

Chen, Z.X., \& Francesco, A.M. (2000). Employee demography, organisational commitment, and turnover intentions in China: Do cultural differences matter? Human Relations, 53(6), 869-887.

Chen, Z.X., Tsui, A.S., \& Farh, J. (2002). Loyalty to supervisor vs. organisational commitment: Relationships to employee performance in China. Journal of Occupational and Organizational Psychology, 75, 339-356.

Clugston, M. (2000). The mediating effects of multidimensional commitment on job satisfaction and intent to leave. Journal of Organizational Behavior, 21, 477-486.

Cohen, A. (2000). The relationship between commitment forms and work outcomes: A comparison of three models. Human Relations, 53(3), 387-417.

Conway, E. (2004). Relating career stage to attitudes towards HR practices and commitment: Evidence of interaction effects? European Journal of Work and Organizational Psychology, 13(4), 417446.

Cook, J. D., Hepworth, S. J., Wall, T. D., \& Warr, P. B. (1981). The experience of work: A compendium and review of 249 measures and their use. London: Academic Press Inc.

Delery, J. E., \& Doty, D. H. (1996). Modes of theorising in strategic human resource management: Tests of universalistic, contingency and configurational performance predictions. Academy of Management Journal, 39(4), 802-835.

Fang, Y. (2001). Turnover propensity and its causes among Singapore nurses: An empirical study. The International Journal of Human Resource Management, 12(5), 859-871. 
Griffeth, R. W., Hom, P. W., \& Gaertner, S. (2000). A meta-analysis of antecedents and correlates of employee turnover: Update, moderator tests and research implications for the next millennium. Journal of Management, 26(3), 463-488.

Guest, D. (1997). Human resource management and performance: A review and research agenda. International Journal of Human Resource Management, 8(3), 263-276.

Guest, D. (2002). Human resource management, corporate performance and employee wellbeing: Building the worker into HRM. The Journal of Industrial Relations, 44(3), 335-358.

Guimaraes, T., \& Igbaria, M. (1992). Determinants of turnover intentions: Comparing ic and is personnel. Information Systems Research, 3(3), 273-303.

Hair, J. F., Black, W. C., Babin, B. J., Anderson, R. E., \& Tatham, R. L. (2006). Multivariate data analysis. New Jersey: Pearson Education.

Huselid, M. A. (1995). The impact of human resource management practices on turnover, productivity and corporate financial performance. Academy of Management Journal, 38, 635-672.

Ichniowski, C., Shaw, K., \& Prennushi, G. (1997). The effects of human resource management practices on productivity: A study of steel finishing lines. The American Economic Review, 87(3), 291-313.

Johlke, M. C., \& Duhan, D. F. (2000). Supervisor communication practices and service employee job outcomes. Journal of Service Research, 3(2), 154-165.

Khatri, N. (2000). Managing human resource for competitive advantage: A study of companies in Singapore. International Journal of Human Resource Management, 11(2), 336-365.
Koh, W. L., \& Yer, L. K. (2000). The impact of the employee-organisation relationship on temporary employees' performance and attitude: Testing a Singaporean sample. International Journal of Human Resource Management, 11(2), 366-387.

Lee, C. H., \& Bruvold, N. T. (2003). Creating value for employees: Investment in employee development. International Journal of Human Resource Management, 14(6), 981-1000.

Liao, H., \& Chuang, A. (2004). A Multilevel investigation of factors influencing employee service performance and customer outcomes. Academy of Management Journal, 47(1), 41-58.

Meyer, J. P., \& Allen, N. J. (1991). A threecomponent conceptualisation of organisational commitment. Human Resource Management Review, 1(1), 6189.

Meyer, J. P., \& Allen, N. J. (1997). Commitment in the workplace: Theory, research, and application. California: Thousand Oaks.

Meyer, J. P., Allen, N. J., \& Smith, C. A. (1993). Commitment to organizations and occupations: Extension and test of a three component conceptualization. Journal of Applied Psychology, 78, 538-551.

Meyer, J. P., \& Smith, C. A. (2000). HRM practices and organisational commitment: Test of a mediation model. Canadian Journal of Administrative Sciences, 17 (4), 319-331.

Meyer, J. P., Stanley, D. J., Herscovitvh, L., \& Topolnytsky, L. (2002). Affective, continuance and normative commitment to the organisation: A meta-analysis of antecedents, correlates and consequences. Journal of Vocational Behavior, 61, 2052. 
Mondy, R. W. \& Noe, R. M. (2005). Human resource management ( $9^{\text {th }}$ ed.). New Jersey: Pearson Prentice Hall.

Mowday, R. T. (1998). Reflections on the study and relevance of organisational commitment. Human Resource Management Review, 8(4), 387-401.

Naumann, E., Widmier, S. M., \& Jackson, D. W., Jr. (2000). Examining the relationship between work attitude and propensity to leave among expatriate salespeople. Journal of Personal Selling \& Sales Management, 20(4), 227-241.

O’Reilly, C., III., \& Chatman, J. (1986). Organisational commitment and psychological attachment: The effects of compliance, identification and internalisation on prosocial behaviour. Journal of Applied Psychology, 71(3), 492-499.

Organ, D.W., \& Konovsky, M. (1989). Cognitive versus affective determinants of organizational citizenship behaviour. Journal of Applied Psychology, 74(1), 157-164.

Organ, D. W., \& Ryan, K. (1995). A meta-analytic review of attitudinal and dispositional predicators of organizational citizenship behavior. Personnel Psychology, 48, 775802.

Paul, A. K., \& Anantharaman, R. N. (2004). Influence of HRM practices on organisational commitment: A study among software professionals in India. Human Resource Development Quarterly, 15(1), 77-88.

Podsakoff, P.M., Ahearne, M., \& Mackenzie, S.B. (1997). Organisational citizenship behaviour and the quantity and quality of work group performance. Journal of Applied Psychology, 82(2), 262-270.
Reichers, A. E. (1985). A review and reconceptualisation of organisational commitment. Academy of Management Review, 10(3), 465-476.

Schumacker, R. E., \& Lomax, R. G. (2004). A beginner's guide to structural equation modeling. New Jersey: Lawrence Erlbaum Associates.

Sekaran, U. (2000). Research methods for business: A skill-buiding approach $\left(3^{\text {rd }}\right.$ ed.). New York: John Wiley and Sons Inc.

Singh, J. (2000). Performance productivity and quality of frontline employees in service organisations. Journal of Marketing, 64, 15-34.

Somers, M. J. (1995). Organisational commitment, turnover and absenteeism: An examination of direct and interaction effects. Journal of Organizational Behavior, 16, 49-58.

Suliman, A. M. T. (2001). Work performance: Is it one thing or many things? The multidimensionality of performance in a middle eastern context. International Journal of Human Resource Management, 12(6), 1049-1061.

Stinglhamber, F., \& Vandenberghe, C. (2003). Organisations and supervisors as sources of support and targets of commitment: A longitudinal study. Journal of Organisational Behavior, 24, 251-270.

Stinglhamber, F., Bentein, K., \& Vandenberghe, C. (2002). Extension of the three-component model of commitment to five foci: Development of measures and substantive test. European Journal of Psychological Assessment, 18(2), 123-138.

Storey, J. (2001). Human resource management today: An assessment. In J. Storey (Ed.), Human resourc management: A critical text (pp3-20). London: Thomson Learning. 
Swailes, S. (2004). Commitment to change: Profiles of commitment and in-role performance. Personnel Review, 33(2), 187-204.

Tsui, A. S., Pearce, J. L., Porter, L. W., \& Tripoli, A. M. (1997). Alternative approaches to the employee-organization relationship: Does investment in employees pay off? Academy of Management Journal, 40(5), 1089-1121.

Vandenberg, R. J., \& Eastman, L. J. (1999). The impact of high involvement work processes on organisational effectiveness: A second-order latent variable approach. Group and Organization Management, 24(3), 300-339.

Vandenberghe, C., Bentein, K., \& Stinglhamber, F. (2004). Affective commitment to the organization, supervisor, and work group: Antecedents and outcomes. Journal of Vocational Behavior, 64(1), 47-71.

Vandewalle, D., Van Dyne, L., \& Kostova, T. (1995). Psychological ownership: An empirical examination of its consequences. Group and Organizational Management, 20(2), 210-226.

Wasti, S. A. (2003). Organisational commitment, turnover intentions and the influence of cultural values. Journal of Occupational and Organizational Psychology, 76, 303321.

Welbourne, T. M., Johnson, D. E., \& Erez, A. (1998). The role-based performance scale: Validity analysis of a theorybased measure. Academy of Management Journal, 41(5), 540-555.
Whitener, E. M. (2001). Do high commitment human resource practices affect employee commitment? A cross-level analysis using hierarchical linear modeling. Journal of Management, 27(5), 515-535.

Wright, P. M., \& Boswell, W. R. (2002). Desegregrating HRM:Areview and synthesis of micro and macro human resource management research. Unpublished manuscript, Cornell University.

Wright, P. M., \& Gardner, T. M. (2003). The Human resource-firm performance relationship: methodological and theoretical challenges. In D. Holman, T. D. Wall, C. W. Clegg, P. Sparrow, \& A. Howard (Eds.), The new workplace: A guide to the human impact of modern working practices (pp. 311-328). West Sussex: John Wiley \& Sons.

Yahya, K. K. (2000). Human resource management practices in the public and private sectors and its implications on employee attitude. In S. Osman, Z. Haji Awang, \& S. Naidu (Eds.), Transforming human resource management in meeting the challenges of the next millenium (pp.203-228). Kuala Lumpur: National Institute of Public Administration.

Yousef, D. A. (2000). Organisational commitment: A mediator of the relationships of leadership behavior with job satisfaction and performance in a non-western country. Journal of Managerial Psychology, 15(1), 6-24.

Zerbe, W. J., Dobni, D., \& Harel, G. H. (1998). Promoting employee service behaviour: The role of perceptions of human resource management practices and service culture. Canadian Journal of Administrative Sciences, 15(2), 165-179. 